\title{
Anti-FGFR3 Antibody-drug Conjugate LY3076226
}

National Cancer Institute

\section{Source}

National Cancer Institute. Anti-FGFR3 Antibody-drug Conjugate LY3076226. NCI

Thesaurus. Code C123829.

An antibody-drug conjug ate (ADC) composed of a human monoclonal antibody ag ainst the fibroblast growth factor receptor type 3 (FGFR3) that is conjug ated to an undisclosed cytotoxic agent, with potential antineoplastic activity. Upon administration, the antibody moiety of anti-FGFR3 ADC LY3076226 binds to FGFR3. Upon internalization, the cytotoxic moiety causes cell death in FGFR3-expressing tumor cells. FGFR3, a receptor tyrosine kinase upregulated or mutated in many tumor cell types, plays a key role in tumor cell proliferation. 